\title{
Frederick Cook, Mountaineering in the Alaskan Wilderness, and the Regeneration of Progressive Era Masculinity
}

Peter L. Bayers Dr.

Fairfield University, pbayers@fairfield.edu

Follow this and additional works at: https://digitalcommons.fairfield.edu/english-facultypubs

Copyright 2003 Western Literature Association - All rights reserved.

Archived with permission from the copyright holder. http://www.unl.edu/plains/western-

american-literature

\section{Peer Reviewed}

\section{Repository Citation}

Bayers, Peter L. Dr., "Frederick Cook, Mountaineering in the Alaskan Wilderness, and the Regeneration of Progressive Era Masculinity" (2003). English Faculty Publications. 68.

https://digitalcommons.fairfield.edu/english-facultypubs/68

\section{Published Citation}

Bayers, Peter. "Frederick Cook, Mountaineering in the Alaskan Wilderness, and the Regeneration of Progressive Era Masculinity," in Western American Literature, 38(2), pp. 171-193, Summer 2003.

This item has been accepted for inclusion in DigitalCommons@Fairfield by an authorized administrator of DigitalCommons@Fairfield. It is brought to you by DigitalCommons@Fairfield with permission from the rightsholder(s) and is protected by copyright and/or related rights. You are free to use this item in any way that is permitted by the copyright and related rights legislation that applies to your use. For other uses, you need to obtain permission from the rights-holder(s) directly, unless additional rights are indicated by a Creative Commons license in the record and/or on the work itself. For more information, please contact digitalcommons@fairfield.edu. 


\section{FREDERICK COOK, MOUNTAINEERING}

\section{IN THE ALASKAN WILDERNESS, \\ AND THE REGENERATION OF \\ PROGRESSIVE ERA MASCULINITY}

\section{PETER L. BAYERS}

From 1903 to 1906, Dr. Frederick A. Cook made three attempts to climb the highest mountain in North America, Denali-known by most Whites of the Progressive Era as Mount McKinley—at 20,320 feet. Cook claimed to have reached the summit of Mount McKinley on his third attempt. As a result, "[b]y the time Cook returned to New York in late November 1906 from his exploits on Mount McKinley, he had moved into the first rank of the world's explorers. That the virgin American territory was explored and conquered by a daring and resourceful native son ... propelled Cook into headlines across the country, and proud countrymen showered him with praise and acclaim" (Abramson 59, italics added). That Cook did not in fact reach the summit of McKinley has been well documented. ${ }^{1}$ Before Cook supposedly climbed McKinley, it was an obscure mountain in the territory of Alaska, but Cook's alleged success brought the mountain into the national consciousness as a symbol of American identity. Cook's narrative about his experiences, To the Top of the Continent: Discovery, Exploration, and Adventure in Sub-arctic Alaska. The First Ascent of Mt. McKinley, 1903-1906, frames his "success" within the discourse of frontier mythology, specifically as that discourse reflected and responded to the needs and desires of many White middle- and upper-middle-class Progressive Era males. Cook's narrative redresses the anxieties of these males who, since the official closing of the frontier, had begun to feel threatened by what they saw as the increasingly feminized version of masculinity, a threat that some thought would undermine the very values which sustained national identity. As a result, many of these men sought to emulate the virile masculine heroes of yesteryear who, through their daring exploits, had defined the essence of manhood and the very core of national identity. Situated within the Alaskan frontier, Cook's narrative is a self-consciously nationalist text replete with the masculine codes of the frontier. Cook portrays himself and his men as frontier heroes-particularly Theodore Roosevelt's version of the frontier hero-who define themselves over and against the Alaskan wilderness and its native 
inhabitants in the name of national identity. Ultimately, Cook suggests that the mountain's topography literally elevates and sanctifies Progressive Era masculinity and national identity as the virile heroes conjoin their bodies with the power of the sublime.

Mount McKinley was first seen by a White man when George Vancouver explored the coast of Alaska in 1794, and the Russians first sighted it in the 1830s, but it was named Mount McKinley in 1896 by a prospector, W. A. Dickey, when William McKinley was nominated for president (Unsworth 223). After he led an expedition that truly reached the summit of the mountain in 1913, Hudson Stuck renamed it Denali, its original Athabascan name, and the mountain is generally known by this name today.

In 1903, Frederick Cook made two attempts to climb the peaktwo months after Judge James Wickersham's short-lived attempt in leading an expedition. Cook's expedition party-with Robert Dunn, Ralph Shainwald, and Fred Printz (Cook's wife accompanied the expedition up the coast of Alaska to Valdez) — did not fare particularly well on their first attempt to climb the mountain, reaching only 8,300 feet. After regrouping and attempting another route on McKinley, the party reached 11,400 feet only to once again turn back when they thought the route was not climbable. Cook abandoned this expedition and returned to McKinley in 1906 with Printz, Barrill, Browne, Beecher, Parker, Raconvenze, Dokkin, Armstrong, Porter, Miller, and Ball. In his narrative, Cook explains that due to the lateness of the season and the non-arrival of additional members of the climbing party, the 1906 expedition decided to disperse and explore different geographical areas near McKinley. Although he initially wanted to take a reconnaissance of the mountain in hopes of discovering a route for a future expedition, Cook claims that he could not pass up the opportunity to climb the mountain with Edward Barrill when optimal climbing conditions presented themselves. According to Cook, he and Barrill reached the summit of McKinley on September 16, 1906, which became national news. While there is still some debate over the truth of their reaching the summit of McKinley, it seems improbable. In fact, soon after the climb, Belmore Browne and others-based on their knowledge of McKinley and the unlikelihood that Cook could have reached the mountain and climbed it in such a short period of time-disputed the claim, and Browne eventually organized his own expeditions in 1910 and 1912 in an effort to prove that Cook's claim was fraudulent. And later Barrill even recanted his story (Unsworth 221-28). Either way, it is important that Cook's book configures him and his men within the triumphant 
discourse of frontier mythology as they confront the Alaskan frontier.

Recent scholarship on the American frontier points out that the idea of a frontier has little to do with an actual geographic area but is a concept invoked to serve ideological purposes. For instance, in his classic essay The Significance of the Frontier in American History (1893), Frederick Jackson Turner conceived of the frontier as an open space of free land despite the fact that Native peoples populated those lands. As Noreen Groover Lape points out, Turner's essay and its assumptions have been highly influential in regard to literary scholarship on the frontier. Largely in reaction to the influence of Turner's thesis, the term itself has been redefined in recent years. Following the scholarship of ethnohistorians, Lape explains that her book West of the Border (2000) "draws on [the] view of frontiers as places where cultures make contact rather than on the Turnerian notion of the frontier as an 'area of free land' traversed by westering pioneers" (5). As reflected in Turner's essay, the image of "free land" in the West was also linked to the discursive construction of "nature" as "wilderness." 2 Ecocritical scholarship "has yielded abundant evidence that 'nature' is not nearly so natural as it seems. Instead, it is a profoundly human construction" (Cronon, "Introduction" 25). David Mazel argues, too, that while the environment is of course a tangible entity which is in great part physically shaped by humans, our ideas about the environment are a "discursive construction" (xii). Similarly, Susan Kollin iterates, "nature is perhaps culture's best invention" (21). Historically, when nature was configured as wilderness, it served the purposes of frontier mythology. Ideas about wilderness were effectively employed by the dominant culture to ideologically erase the legitimacy of indigenous peoples on the American frontier. Implicitly, since the wilderness was supposedly pristine and untouched by humans, indigenous peoples were seemingly absent from the geography, making it easier to dismiss their claims to land (Kollin 20). William Cronon points out that in "the decades following the Civil War," the notion of "wilderness came to embody the national frontier myth, standing for the wild freedom of America's past and seeming to represent a highly attractive natural alternative to the ugly artificiality of modern civilization" ("Trouble" 78). During the Progressive Era, the wilderness represented an arena in which AngloSaxon males could renew their imagined primal bonds with wild nature, in turn regenerating the supposed primal virility of Anglo-Saxon masculinity. As I will illustrate, Cook configures the Alaskan landscape as a frontier wilderness-largely at the expense of Alaska Natives-to serve the ideological interests of elite White males. 
At the time, many White middle- and upper-middle-class males believed that the rugged, masculine virtues exemplified by what they saw as the virility of the frontiersman were being suffocated by modern civilization. To their dismay, American White males no longer had the opportunity to blaze trails in hostile Indian territory; instead, they were sitting at desks quietly performing their mundane, regimented working roles in an overcivilized world. Rather than protecting innocent women and children from the ravages of marauding Indians, they were now domesticated husbands and fathers providing for their families' material comforts. In a world led by Teddy Roosevelt-an emblem of male anxieties--if men did not mirror the "virile" masculinity of the frontier hero, the very future of the nation was at stake. As many critics have argued, the "inherent" values inscribed within frontier mythology were replayed in multifarious mediums-the press, the Boy Scouts, Wild West shows, sensational "real life" adventures, frontier literature, to name a few-in order to regenerate the national moral virtue of America after the closing of the frontier signaled by Turner's famous essay (which was inspired by the results of the 1890 census). Roderick Nash writes, "Good, fat, and cocksure as the years between 1900 and 1916 were, the rosy glow could not entirely obscure a deep, almost subconscious anxiety which revealed itself in the compulsive urge to prove the national vitality and to heed the multi-faceted call of the wild," which was intimately linked to definitions of White middle- and uppermiddle-class masculinity (Introduction 3-4). In the minds of these men, the Far North of Alaska was an important extension of the frontier, for it offered an imaginative proving ground to relieve masculine anxieties concerning the closing of the frontier.

In the interests of imperial expansion dating back to the eighteenth century, Spain, Great Britain, France, and the United States had explored Alaska's coast, but they all failed in their attempts to make Alaska part of their imperial projects. Only the Russians made any serious attempt to colonize Alaska, and it remained their colony until 1867, when Secretary of State William H. Seward negotiated on behalf of the United States for its purchase from Russia. In addition to promoting the value of its natural resources, Seward had lobbied for the purchase of Alaska in order to better establish a U.S. geographical perimeter for markets overseas. Seward also hoped the purchase would be followed by the United States' annexation of British Columbia, thereby creating a geographically contiguous United States, which would position the United States to "secure continuous ... rule throughout the [Western] hemisphere" (Kollin 7). ${ }^{3}$ Richard Welch 
points out that most newspapers across the United States looked favorably upon or did not oppose the purchase of Alaska, expecting it to provide significant economic opportunities for the United States; however, many U.S. citizens preferred to think of the purchase of Alaska as "Seward's Folly" because they perceived Alaska as a useless, "frozen wasteland" (Kollin 29). 4 The annexation of British Columbia, of course, never materialized, and as a result, Alaska came to occupy an ambivalent spot in the nation's geography. As a geographically isolated

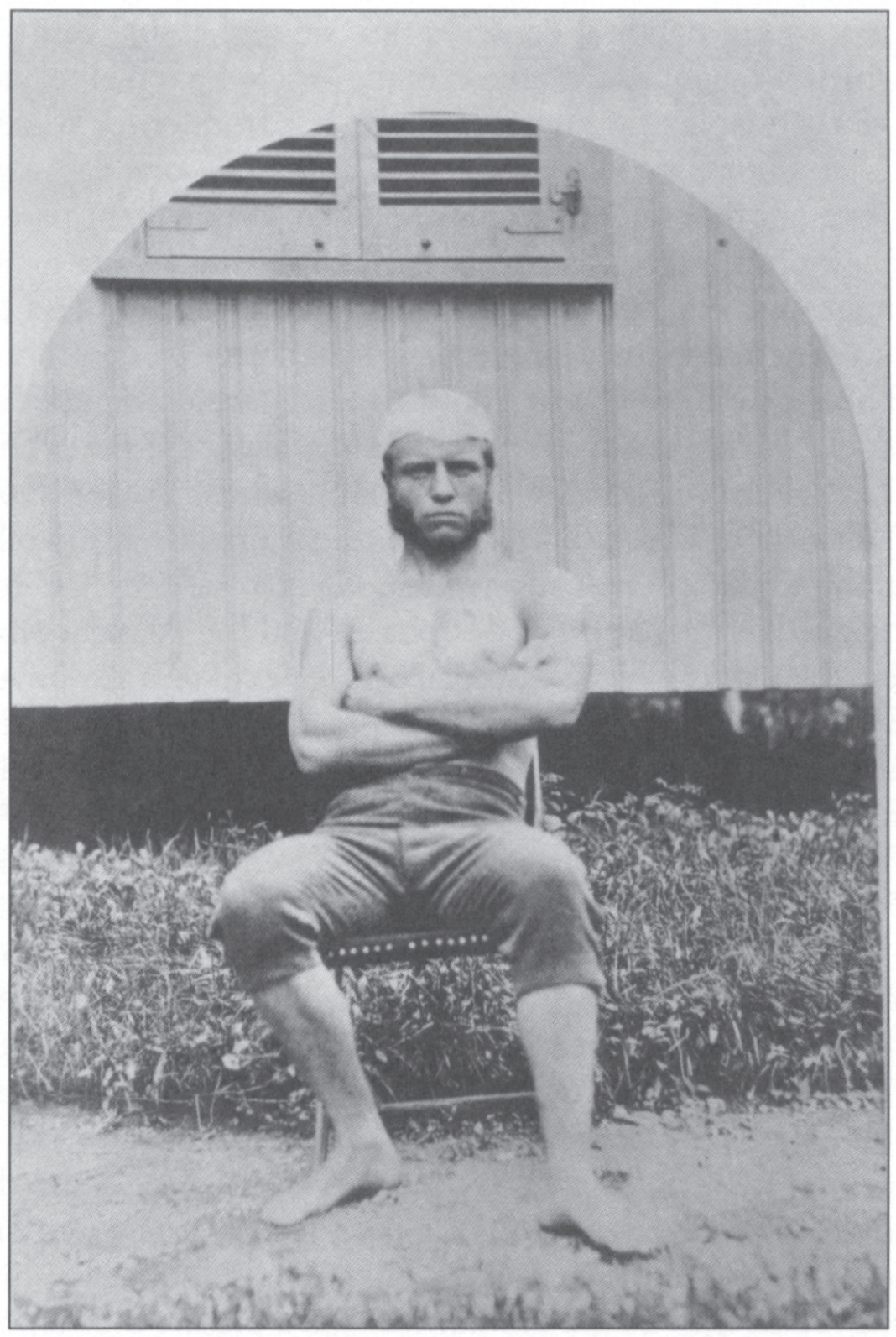

Theodore Roosevelt in his sculling outfit at Harvard. He participated in rowing and boxing. Ca. 1877. Theodore Roosevelt Collection, Harvard College Library. 
territory, it did not fit easily into the paradigm of an uninterrupted, geographically contiguous U.S. expansion (Kollin 7). ${ }^{5}$ However, although the Alaskan territory could not be smoothly linked to the United States' geographical expansion, it slowly became ideologically linked to the frontier myth. Its coastline was explored by and written about by the likes of John Muir and Samuel Young, both of whom helped lay the groundwork for the image of Alaska as a last frontier. ${ }^{6}$ Its interior, which had been sparsely explored by the Russians, remained relatively unexplored by Whites, and for the most part Alaska remained on the periphery of the national consciousness until the gold rush of 1898 , after which it caught the attention of the Anglo-Saxon elite and began to serve the ideological purposes of the last frontier for these White middle- and upper-middle-class males. In a sense, one can argue that the failure of other nations to make Alaska a permanent part of their national projects served to underscore its value for White men during the Progressive Era. Whereas the men of other nations had failed in Alaska, U.S. males could prove their superiority by confronting and triumphing over the Alaskan frontier, thereby validating the health of the nation. For these adventurous White males, "the Far North functioned as a site of white flight, a new frontier where Anglo Saxon males could reenact conquest and reclaim their manliness" (Kollin 63). According to Theodore Catton, "The Alaskan wilderness setting was mythologized as the nation's 'last frontier,' and the Alaskan prospector, or 'sourdough,' fittingly took his place at the center of this myth-just as the cowboy had captured the role of mythic hero in the Far West a generation earlier, and the hunter-pathfinder had been made into the romantic hero of the old frontier a generation before that" (89-90).

That Cook's heroic adventure takes place on the Alaskan landscape in and of itself makes it a frontier wilderness narrative, but Cook explicitly situates his adventure as a frontier quest, comparing the Alaskan scenery to the West. Reaching a "great treeless plain," he writes, "[o]n this grassy expanse, looking over the numerous lakes of the lower plains, we saw many caribou, feeding with the contentment of cattle on our Western prairies" (43). Later, he draws an analogy between the trials of his men in the Alaskan wilderness and the trials of frontier pioneers. Describing his pack train's attempt to cross the raging Yentna River, he explains, "The men and horses rushing over seething rapids into a land unknown made a picture of pioneer life as primitive as that of the early Western frontiersmen" (137). Similarly, in his "Introductory," Cook refers to the expedition as a "pioneer adventure" done in the "pioneer spirit of conquest" (xvi). 
Cook makes it clear that this "pioneer adventure" should not be relegated to a small footnote in the grand narrative of frontier conquest; instead, his expeditions assume a role of mythically romantic proportions, seemingly worthy of measure on the scale of the Lewis and Clark expedition, John Charles Fremont's exploration of the West, and Daniel Boone's opening of the Cumberland Gap. Cook writes,

In the development of the project for the conquest of the mountain which this volume narrates, a series of barriers arose which seemed almost unsurmountable [sic]. A great mountain was rediscovered in an unexplored district and christened in honour of our late President, William McKinley. Preliminary investigation proved this mountain to be the highest peak in North America. Hidden in the heart of Alaska, far from the sea, far from all lines of travel, this newly crowned alpine rival pierced the frosty blue of the Arctic within reach of the midnight sun. (xv)

Following the frontier hero ethos, Cook defines his expedition in distinctly masculine discourse. He is a frontier hero forging his identity against the nearly "insurmountable" Alaskan wilderness and his "alpine rival." As a threatening rival, the wilderness implicitly requires a powerful hero to subdue this threat. According to Cook, Mount McKinley, obscured from civilization in the Alaskan wilderness before it was climbed, had assumed a mysterious, almost metaphysical aura beyond the limitations of human knowledge as it pierced the sky "within reach of the midnight sun." Cook reiterates the expedition's significance as a national quest narrative by claiming that "[t]he recognition of the preeminence of this peak, together with its fitting designation, framed a national mountaineering challenge" (xv). The entire narrative is subsumed under the ideology of nationalism.

That the mountain is named after a U.S. president underscores the narrative's ideological significance as a national quest narrative. Cook recounts the debates about the appropriate name for the mountain.

A good deal has been said bearing on the wisdom of placing a modern name over a landmark that would seem to have been recognised and named for ages. We have taken much trouble to clear this point, but up to the present have been unable to trace a name which was previously used to specifically designate this particular peak. The Russians applied the name Bolshoy, meaning big, to many high mountains, and this name was given to the peak in question with its compan- 
ion peaks in the central group. Thus Bolshoy was the general name for the highest section of the Alaska Range. The Susitna Indians gave the name To-lah-gah to the same group. Therefore the new name Mt. McKinley finds a proper setting to a fitting monument as a token of appreciation to the memory of one of our greatest statesmen. (xviii-xix)

Granted, Cook acknowledges that the indigenous peoples such as the Susitna Indians had a name for the mountain chain, but for Cook these names are easily displaced because "up to the present" there is no known "specific" name for the peak. Cook fails to acknowledge that the peak itself was called Denali by the Athabascan Indians, a wellknown and large Alaska Native nation inhabiting the area near the mountain. Rather than recognize the legitimacy of Alaska Native claims to the land, Cook uses geography to serve the ideological interests of national possession. Knowledge is mediated by White culture, and the "naming or renaming of a place [or] ... a region ... [,] like all acts of primordial nomination, [is] an act of possession" (Deane 18). ${ }^{7}$ To Cook, logic dictates that the peak should be named after McKinley given the "proper setting" of the mountain in the Alaskan wilderness. The mountain becomes, as it presumably should be, a patriotic icon of U.S. identity. The Alaskan frontier, or what was the frontier until Cook supposedly reached McKinley's summit, properly represents what the frontier has always been in American literary and cultural history: a landscape which foregrounds national identity.

In addition to the name of the mountain itself and in common with mountaineering narratives, Cook labels its other geographic features, which in this case help to amplify the narrative's intimate connection to the ideologies of Progressive Era masculinity and nationalism. Regarding a ridge on McKinley, Cook decides that "[f]or this unique geographical feature I have placed in honour of our President the name 'Roosevelt Ridge'" (73). In a Progressive Era frontier narrative which displays how White male explorers subdue the frontier wilderness, it is all the more appropriate that Roosevelt's name should be invoked to label the ridge, for, in Gail Bederman's words, "[a]s [Roosevelt] saw it, history proved that manhood and race were integrally connected — almost identical — and the future of the American nation depended on both. History showed that ... superior manhood itself had allowed the American race to prevail against the Indians, win a continent, and build a mighty nation" (183). In that the narrative is about Cook and his men's "superior manhood" which "wins" against 


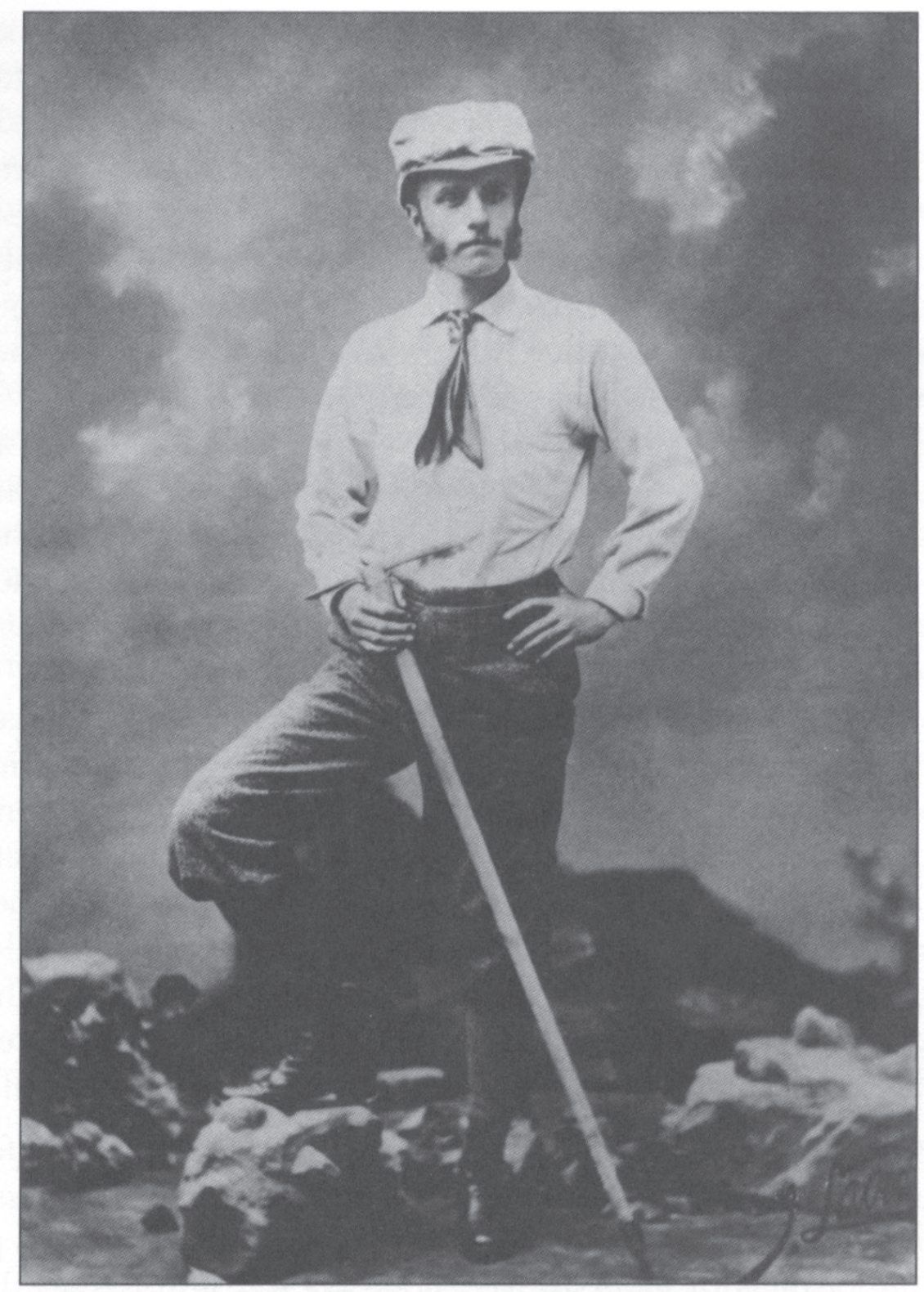

During his wedding trip to Europe in 1881, Theodore Roosevelt climbed the Matterhorn. To commemorate the occasion, he had this studio photo taken. Theodore Roosevelt Collection, Harvard College Library.

the rigors of the mountain, their quest is implicitly conjoined with Roosevelt's version of history. Throughout Cook's narrative, the moral attributes of the climbers reflect Roosevelt's heroic masculine discourse. For instance, following Cook's pronouncement that climbing McKinley was "a national mountaineering challenge," he writes that it was one "which we took up fully realising the strenuous task which it entailed" (xv). Cook's configuration of the expedition as a "strenuous 
task" echoes the phrase so famously (or infamously) coined by Roosevelt, who in his 1899 essay advocating U.S. imperialism, "The Strenuous Life," called for the regeneration of virile masculinity if the United States was to maintain its position as a dominant world power. The strenuous ethic is reinforced here, implicitly linking Cook's alleged conquest of the wilderness to the larger agenda of U.S. expansionism. Cook's writing follows a trait of other modern mountaineering narratives and their configuration of geographical space, which, as Reuben Ellis has shown, are intimately linked to ideologies of American imperialism (41).

In accordance with the strenuous frontier ethic, Cook and his men hunt for much of their food. In Cook's chapter 4, "Through the World's Best Big Game Country," he not only describes the hunt for game but also argues that the land surrounding McKinley should be preserved as big game country, paralleling the wilderness ethos championed by Roosevelt, who believed that the preservation of the American wilderness was crucial to the sustenance of American masculine identity. For Roosevelt, big game hunting enabled American men to tap their "innate" savagery in order to combat the dangers of overcivilization. Roosevelt had founded the Boone and Crockett Club in the 1880 s to specifically address what he saw as the needs of American male identity, and at the turn of the century, the club lobbied Congress to create a big game preserve in Alaska. The club believed that local professional hunters, including Indians, threatened the big game population in Alaska. Through their lobbying efforts,

[t]he sportsmen achieved their first major victory for conservation in Alaska with the enactment by Congress of an Alaska Game Law in 1902. This was followed by the passage of a slightly more stringent code in 1908. Still, despite the law's federal jurisdiction, there was so little enforcement that it was practically useless. Members of the Boone and Crockett Club agreed that stronger measures were required to protect the game, and they looked to the creation of game preserves as their most important objective in Alaska. (Catton 94)

For these men, the preservation of big game was specifically linked to the frontier myth. They hoped that the Alaskan landscape would become a living, breathing, permanently sustainable frontier wilderness where the American White male could forever regenerate his masculinity. ${ }^{8}$ An advocate of preservation, Cook opens his chapter, "We now entered Nimrod's [hunter's] dreamland. To the west were ten thousand square miles of unexplored territory" (35). Cook and each of his 
men symbolize the consummate frontiersman entering the "unexplored territory" of a bountiful wilderness, "untouched" by "civilization." Cook explains, "[Claribou were sufficiently abundant to supply our larder without interrupting the long marches. ... [W] saw moose. ... [W] saw great bands of mountain sheep, while everywhere there were fresh signs of bear. Here, wandering with primeval freedom, were the largest of the big game animals. Surely, it is the finest game preserve in all the world" (43-44). The image of the Alaskan landscape as a timeless, fertile wilderness echoes the long-held trope of the American frontier. In this passage, nature does not threaten the frontiersman; rather, nature seemingly beseeches the White hunter's presence. The men seem as if they are part and parcel of the primeval landscape, and thus they become primeval, "natural" men seamlessly interacting with the wilderness.

But the corrupted mores of civilization threaten the primeval wilderness and by extension the "natural man." Echoing Hawkeye's lament over the pigeon slaughter in James Fenimore Cooper's The Pioneers (1823), Cook bemoans that the excesses of Indians and prospectors are destroying the Alaskan wilderness. As such, he argues,

It behooves us to protect these splendid animals against the cruel slaughter which blots the history of wild life in the past decade. Game preservation is too long a subject to take up here, but my admiration for the noble creatures that run to untroubled joys along the west of this range impels a word of caution. Some game law must be framed for this undisturbed wilderness will soon be spotted with the blood of innocent creatures to satisfy the murderous lust of man's instinct to kill. The present game laws of Alaska are a farce in their effect. They favour the Indian and the prospector but permit the wholesale extermination of the game. The only result of this law is to keep big game hunters out of that territory and to make a closed field for the Indian and the prospector to slaughter at will. (44)

Although "[t]he spirit of the law and the generally accepted theory is to curb the outside hunter and allow the native a free hand with minor restrictions," Cook argues that "[t]his theory in Alaska is a misfit" (44). The law was supposedly designed to allow the Alaska Native and the prospector to engage in subsistence hunting, but, according to Cook, "[t]he Indian about Cook Inlet and the Alaska Range is to-day, and always has been, a fish eater. He secures his yearly supply of salmon with such ease and despatch that for his own use he does not seriously 
trouble the game. It is only since the advent of the white man with rapid-fire guns and a market for skins that he has taken to the hunt of big game. The ultimate object of this chase is easily gotten revenue, not meat" (44-45). While Cook takes the prospector to task, much of his ire is reserved for Alaska Natives. Unlike the White hunter, who "is a lover of animal life" and "does not seriously affect reproduction ... [,] the Indian and the prospector slaughter indiscriminately, females and young, and all living things" (45-46). Moreover, Cook explains that "[n]ear the head waters of the Skwentna River there are thousands of square feet covered with moose hair to the depth of three feet. Here Indians have massacred hundreds of moose in the deep snows, taking only the skins for souvenir moccasins, leaving heaps of heads and tons of meat to rot" (46).

There is no question, of course, that Alaska Native cultures were changed by the "white man with rapid-fire guns," but in order to combat this change, Cook wants to somehow preserve Alaska Native culture in a time capsule, much in the same way that he wants to preserve the "primeval" wilderness-and rapid-fire guns in the hands of squandering Indians destroy their "natural role" in that primeval wilderness. Yet while Cook acknowledges that it was the influence of the White man which transformed Alaska Native culture, it does not seem to occur to him that the presence of Whites was invasive in the first place. The Alaska Natives now ascribe to White capitalist values that exploit natural resources for economic profit, slaughtering animals to feed the rapacious desires of U.S. consumers. Ironically, their ethos echoes the slaughter of the American bison on the western frontier, a slaughter that was perpetrated by White hunters such as Buffalo Bill. For Cook, the solution to the problem is not for Whites to restore the land to its native inhabitants but to arbitrate the land's use with the specific goal of serving a particular type of White man-the nimrod. Cook contends that "It]he nimrod's claim to consideration is at least as good as that of the Indian and prospector, and the law in my judgement should be so reconstructed" (45). Although Cook argues that the nimrod's claim "is at least as good" as that of the Indian or the prospector, he clearly implies that it is actually superior because of the Indian's as well as the prospector's blatant misuse of the innocent creatures. Like the image of the innocent wilderness itself, the White hunter figuratively embodies innocence as he interacts with the pristine wilderness, thus regenerating the myth of a harmless course of expansion on the western frontier.

The irony of Cook's belief that the nimrod is better suited to manage the wilderness than Indians is that the virtues of the White hunter 
of the frontier myth are in part modeled on a White, mythological stereotype of the culturally uncorrupted Indian. In the frontier myth, the frontier hero identifies with virile Indians and their way of life, learning their skills in order to survive in the wilderness. However, although the frontier hero identifies with the attributes of the Indian, he is always conscious of his assumed racial superiority. In fact, because of his racial superiority, the frontier hero not only emulates the Indian but also employs his skills in a fashion superior to that of the Indian, for he knows Indians better than they could possibly know themselves. ${ }^{9}$ As I will show, Cook and his men follow this paradigm, for they mimic the mythological, imagined Indian in that they are able to survive while in close contact with the raw wilderness.

Cook also contends with various real life Alaska Native characters in his narrative, and they serve as fodder for the shaping of AngloSaxon masculinity, making it all the more easy to dismiss their hunting rights in Alaska. The Indian might have much about him which deserves admiration, but his intellect and culture are nonetheless limited because of his racial and cultural inferiority. Cook stereotypes the Alaska Native in a number of ways: either as the "noble savage," who while not capable of higher reason is nonetheless attuned to high moral virtues because of his intimate, innocent connection to nature; as the "bad" savage Indian, which for Cook's purposes means indolent, deceitful, and superstitious; or finally, and in different degrees depending on Cook's needs, as the morally bankrupt savage, or a version of what Robert Berkhofer calls the "degraded Indian," who embodies some of the worst traits of White and Indian culture because he is incapable of fully assimilating to "civilized" society. ${ }^{10}$ In any case, the uncivilized savage becomes the Other against which Cook measures his self-definition as a racially and culturally superior being. By stereotyping Alaska Natives, Cook attempts to diminish their threat to White masculinity and its claims to Alaska.

To aid the expedition, Cook employs Indian guides, one of whom helps the White men navigate the Susitna River. In the frontier myth, the Indian guide has intimate knowledge of the natural world, which makes him a valuable asset for the White man. In this vein, Cook explains that "Stephen, the son of the [local] Chief, was secured. He was a trustworthy and intelligent young man who had been in our employ on our previous expedition. Stephen took the helm and guided us very well, jumping tree trunks and gravel bars as occasion demanded" (108). Initially, it seems that Stephen embodies the virtuous Indian guide, particularly because he is the son of a chief, a figure 
who in frontier legend embodies the wise and "trustworthy" traits of the noble savage. But as Cook explains, "The shore line was rushing past at the rate of fifteen miles an hour and after a half-hour of Indian pilotage we decided that a better knowledge of power boating was more important than an expert knowledge of the river bottom. So Miller took the wheel" (108-9). For the safety of the crew and the preservation of the boat, Cook may very well have been justified in replacing Stephen at the helm, but Stephen's failed pilotage is characterized as Indian pilotage. Stephen the individual does not abuse the power boat; rather, what appears to be an inherent Indian characteristic causes him to mishandle the boat. As a noble savage, Stephen has intimate knowledge of the natural world, but as an Indian feebly attempting to handle a boat, his pilotage is ultimately useless-he is unable to recognize how his lack of navigational skills endanger the boat. Put him in a "civilized" boat and he is removed from his "natural" element, for Stephen's implied intellectual limitations inhibit his ability to master a craft which is produced by a technically superior culture. Yet as a White man, Cook's superiority allows him to combine the best of both worlds: his identification with the Indian's innate knowledge of nature and his use of "civilized" technology save the boat from destruction.

An Indian guide, Pete, hired for the trek inland, functions similarly to Stephen. Although he finds Pete a likeable character, Cook explains that "his appalling laziness was a bad example for the discipline of our party" (161). Pete represents the stereotypically lazy Indian, and similarly to Stephen, Pete supposedly has limited reasoning skills, for he assumes that the party must be searching for gold. Given the historical circumstances, it would not be surprising that Pete should distrust the party. After all, at this time the great majority of the White population in Alaska were prospectors, and Pete had witnessed the gold rush at the end of the nineteenth century. Any White in Alaska who was not a prospector was living in boomtowns to profit off the miners. Cook acknowledges that Pete's "contact with the miners led him to the conclusion that the new invasion was for gold. There could be no other incentive to push so desperately into a land of hardships" (161). Nonetheless, he belittles Pete and his suspicions.

The mountain-climbing project he was not inclined to take seriously, but he also began to doubt our mission for gold, for he showed us gold and we did not stake the ground as did the prospectors. Instead of using the picks, the shovel and pan, we went about with pencil and paper and all kinds of instru- 
ments, which he did not understand. The cameras, the barometers, the thermometers, the prismatic compass, and all of the other apparatus came in for a careful scrutiny. When the topographer got out his plane table, theodolite, and steel tape and began to measure a base line, then Pete looked up with a sigh of relief, for according to his understanding we were measuring off claims. (165)

As in the anecdote with Stephen and the boat, Pete's limited understanding of the scientific equipment amplifies his cultural distance from it. However, it is not configured in terms of cultural relativism (he is not inferior because of his lack of working knowledge about the equipment); instead, his inferiority stems from his inability to fathom the equipment's true purpose. The scientific equipment represents the rationalism of Western culture while Pete's inability to comprehend the equipment's purpose represents his irrational savagery. Yet the notion of Whites going up a mountain and down again for no ostensible material profit would seem utterly incomprehensible to Pete, and Cook never explains to Pete the reasons for the expedition. Continuing his mockery of Pete, Cook writes,

At last he had discovered our real vocation. All of this strange apparatus was to locate wild animals and in some mysterious way to place the gold deposits on a map, and for several days he made himself comfortable about camp at our expense to verify his guesses at our mission. As a guide Pete was a failure, for our horsemen preferred to pick their own way. But as a character study he made a splendid model. (165)

Not comprehending the purpose of the expedition leads Pete to deviate from his assigned duties, costing the expedition money, but as a "character study," Pete represents the quintessential inept Indian against which the superior White men gain their self-definition. As the omniscient White frontiersman, Cook knows the Indian better than he can know himself, since Cook studies the Indian's innate character. ${ }^{11}$

Yet for all Cook's ridicule of Indians, all of his versions of "the" Indian are not without merit. While the likes of Stephen and Pete work to safely underscore White cultural superiority, an idealized archetype of the Indian is still a necessary tool for reinvigorating White masculine virility. If the White man identifies with the "savage Indian," he can regenerate his own dormant virility. For Cook, the frontier wilderness serves as a means to shed the veneer of civilization by exposing White 
masculine virtues in their raw and primeval state, much like those of the "savage" Indian of frontier legend. For instance, Cook explains,

In this northland, where dusk and dawn run together, men get into the real swing of nature and close to each other's hearts at the camp-fire. There is something about the crackle of the fire, the inspiration of the blaze, and the long frosty nights of twilight, which bares the breast of each camper to the scrutiny of his companions. At the club a man may be a good fellow superficially, with the veneer of a make-believe spirit of human brotherhood over a selfish centre of commonplace discord, but in the sub-arctic wilderness this is impossible. Naked manliness under togs that are stripped and dried at the evening round-up with the aroma of the spruce and the music of the forest wilds, is the ultimate necessity of every adept. (41)

Gathered around the fire in the raw wilderness, the White men become "natural men." Like the noble savage, their contact with raw nature reestablishes the natural virtues so necessary to regenerate and sustain U.S. masculinity. The homosocial image of brotherhood serves to underscore how the frontier wilderness not only can rejuvenate individual men, but more importantly a communal image of White men around the fire symbolically reestablishes how the wilderness acts to rejuvenate the virility of the entire nation of men.

In their "naked" manliness, Cook suggestively creates an image of the male body exposed to the frontier wilderness, implicitly tapping into the image of the virile Indian with whom the frontier hero can identify. Cook explicitly calls on the need to restore Anglo-Saxon bodily virility later in his narrative.

How different are the life-sapping conditions of modern city life. Physical exercise is prohibited by the limits of space and the ease of mechanical locomotion; mental energy is strained to cope with the maddening pace of this material age. The stomach is abused by unnatural foods, the liver and kidneys are hardened by poisonous drink, the lungs breathe a hothouse, germ-cultivated air, the muscles wither from disease, the whole splendid cellular organisation is disarranged in an endeavour to fit man into an artificial environment for which animal life was never intended. The misfits result noticeably in the breaking down of some important department of biologic association, and disease follows. (185) 
Cook echoes Progressive Era fears about the feminization of the White male body due to overcivilization. In response, "thousands of [Progressive Era] American men trooped off to gyms and athletic fields as part of a national health craze, there to acquire manly physiques, shore up flagging energy, and develop masculine hardiness as ways of countering the perceived feminization of culture. The health craze was vital to the perpetuation of a virile nation" (Kimmel 126). It is clear that Cook is preoccupied with the need to improve the U.S. elite's body image. The West was seen as the perfect place in which to achieve the ideal physique. Following the lead of luminaries such as Roosevelt, Wister, Remington, and Eakins, White middle- and upper-middle-class Progressive Era men traveled to dude ranches in order to renew their manhood by "[r]iding the range, breathing the fresh country air, and exerting the body" (Kimmel 135). The restoration of Anglo-Saxon manliness had, they thought, implications for their ability to maintain their privileged status as leaders of the nation. As Gail Bederman writes, "[T]he metonymic process of turn-of-the-century manhood con-

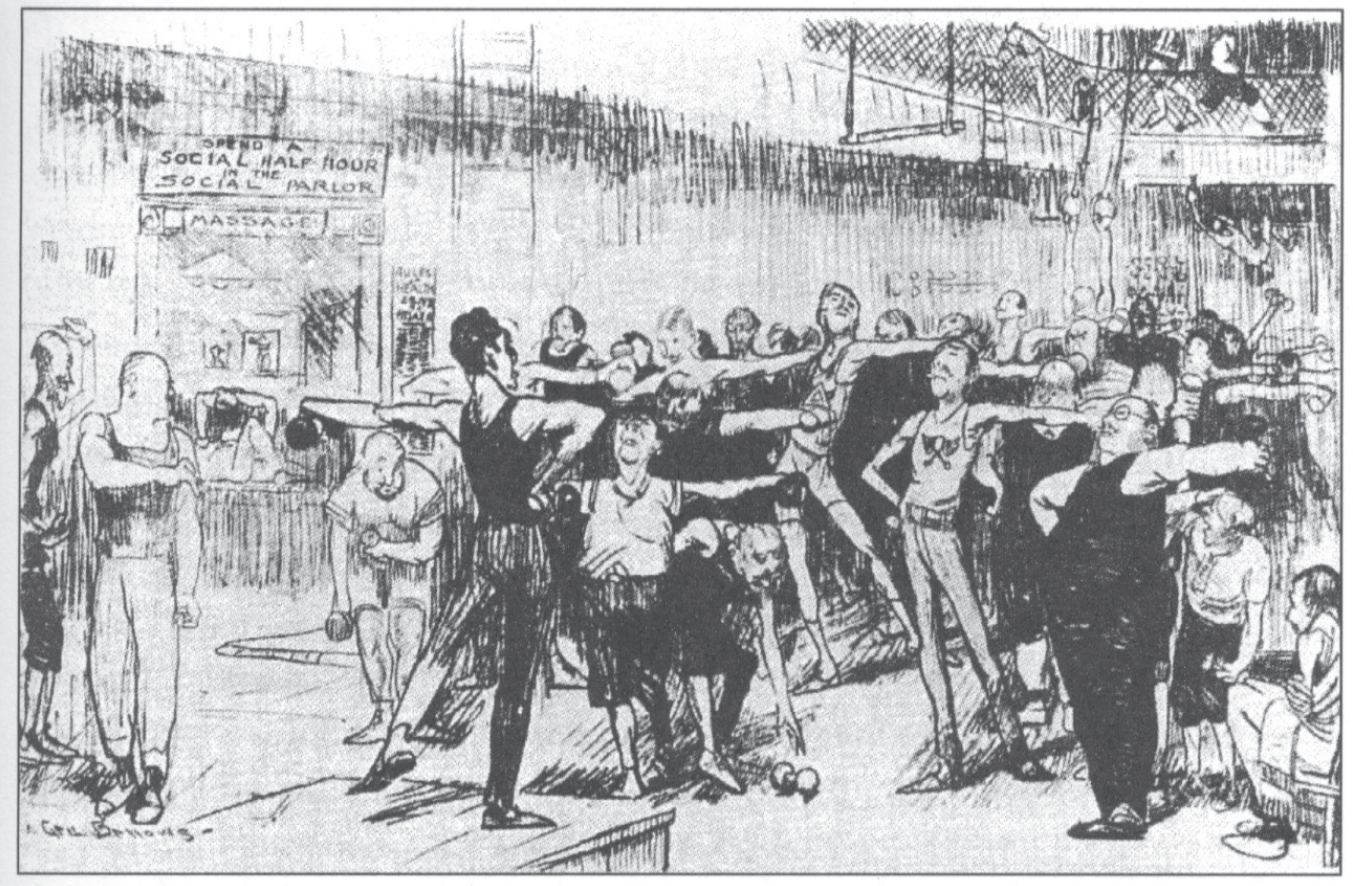

George Bellows. "SUPERIOR BRAINS": THE BUSINESS MEN'S CLASS. Lithograph. From The Masses 4 (April 1913). T This satiric graphic was one of very few examples of its time in which undesirable, middle-class, White, male bodies were displayed. The large number of flabby, overweight people was attributed to "brain work." The artist here pokes fun at the fitness craze that promised athletic physiques to out-of-shape office workers. 
structed bodily strength and social authority as identical" (8). Cook's narrative clearly reflects an obsession with the body, and he seeks to project his and his expedition members' physical strength as a symbol of White middle- and upper-middle-class "social authority," for, as Cook writes, "[i]f mountaineering has no other recompense than to act as a means to arouse dormant functions and to establish a normal balance in the laboratory of human economy, it is a boon to mankind" (185). With this claim, Cook extends the significance of his expedition to the entire nation. As goes the "virile" health of White male mountaineers, so goes the "virile" health of the nation.

The struggle to test this virility is underscored by Cook's use of martial discourse to describe climbing McKinley. According to Cook, the men are "on the battle-ground and in the firing line of clouds from the tropic and the arctic"; he also describes the "lines of attack" up the mountain $(207,212)$. In perhaps the most explicitly martial passage, Cook writes, "Mt. McKinley is one of the severest battle-grounds of nature, and warfare is impressed with every look at its thundering immensity. The avalanches fire a thousand cannons every minute and the perpetual roar echoes and re-echoes from a hundred cliffs. The pounding of the massive blocks from ledge to ledge in their mad descent makes the whole mountain world quiver with battle spirit" (203-4). Later he claims, "The night was dark and we were restless like soldiers on the eve of a batthe" (205). Violent martial discourse, of course, amplifies the climbers' virility, and for Teddy Roosevelt and the men of the Progressive Era who identified with his masculine ethos, war was the consummate proving ground for masculinity. ${ }^{12}$ While earlier in the narrative Cook identifies with a receptive, nurturing wilderness as a means to regenerate male virility, in the end, as Richard Slotkin has shown, the frontier male must regenerate himself "through violence." In frontier mythology, the wilderness and/or Indian must ultimately become a threat which the frontier hero-and in this case heroes-must overpower and subdue if he is to realize his manhood, metonymically regenerating the nation as well. ${ }^{13}$ In Cook's narrative, the men dominate the mountain and are amply rewarded as exemplars of natural male identity. The martial rigor of Cook and Barrill's assault on the mountain leads to their bodily deprivation. The men spend sleepless, uncomfortable nights on the mountain, and, Cook explains, because of the demands imposed upon the body due to high altitude climbing, "[i]n picking a way among the séracs we soon found that our muscles refused to work. Though the climb was easy we could not gather enough energy to continue the ascent. The night in the ditch and the prolonged expenditure of energy along the 
middle slopes had pressed us to the verge of collapse" (219-20). As a result, the men decide to rest a day before heading to the top (220). Bodily deprivation, however, has its rewards.

For Cook, climbing McKinley and enduring the bodily hardships imposed by the harsh wilderness leads to sublime spiritual regeneration. William Cronon points out that in the nineteenth century, the sublime power of the wilderness signified the sublime power of U.S. national identity ("Trouble" 72-76). Cook's narrative forges a connection between the White male body and the sublime American wilderness, figuratively amplifying Anglo-Saxon male power. He explains, "The upper world of silent glory and snowy wonder was beyond human interpretation" (222). His inability to interpret the "upper world" invokes the romantic discourse of the sublime, and this discourse suggests the potential reward for the male hero should he reach the top of McKinleycontact with the power of sublime ideals. Cook writes, "I am bound to confess that I believe the spiritual future which we in a figurative way style heaven is very near the terrestrial surface. As we ascended into this cloud world we thought of angels in light attire with wings, and of an easy world of rare glory" (223). Although at times the ideal seems illusory ("But how different was our realisation. ... [W] we were submerged by a gloomy darkness preceded and followed by icy gusts of wind. ... This environment of the cloud world was indeed opposed to a heavenly or even a congenial spirit. We were in a desperate mood, without poetry or aesthetic appreciation" [223-24].), Cook and Barrill endure bodily hardship to ultimately realize this ideal. Without their struggle, the body would not seem innately virile. Although, the night before their summit bid, he and Barrill endure "a restless and exciting night," Cook claims that it was "[e]xciting, because with heaving, pulsating bodies we felt as if the end of life had come and the door of heaven was about to open" (227). And although they continue to endure misery as "all of the pleasurable sensations had merged with the strain of the terrible task of climbing" and "all of the spirit of the joys of the pioneer ascent has been put into the slavish bent to press one foot above another to the summit," Cook and Barrill do finally reach the summit and conjoin their physical bodies with the sublime ideal (228). "Just below the summit we dropped over an icy shelf on the verge of collapse. ... We edged up along a steep snowy ridge and over the heaven-scraped granite to the top. AT LAST! The soul-stirring task was crowned with victory; the top of the continent was under our feet" (231). Atop "heaven-scraped granite," Cook and Barrill seem to enter the realm of the transcendent ideal, in turn sanctifying masculine 
frontier ideology. Following Slotkin, the frontier hero seems literally initiated into "a higher state of being or manhood" (Regeneration 22). Cook's and Barrill's bodily virility enables the conjunction between the material body and the sublime on the summit of McKinley, suggesting that they are able to internalize the power of the sublime, ultimately projecting this sublime virile power over and against the wilderness and Indians. The frontier hero and frontier ideologies are no longer historical artifacts, but metaphysical, masculine ideals.

For Cook, then, McKinley is not another frontier lost before the march of civilization. Instead, the mountain can serve as an enduring, living, breathing, forever renewable exemplar of the frontier through and against which American men can regenerate themselves as well as a national identity. He writes,

The mountain climber and the arctic explorer in their exploits run to kindred attainments. ... [B]oth suffer a similar train of hardships, which hardships are followed by a similar movement of mental awakening, of spiritual aspirations, and of profound and peculiar philosophy. Thus the stream of a new hope, of dreams and raptures is started, and this stream seeks a groove down the path of life for ever after. It follows that he who ventures into the polar arena or the cloud battlefield of high mountains will long to return again and again to the scene of his suffering and inspiration. This return habit or migratory spirit is a curious study in one of the first primitive instincts and its most potent factor is the joy of discovery and exploration. (xvii-xviii, italics added)

Apparently, the unique topography of McKinley allows it to always remain a permanent transcendental arena of the frontier wilderness. McKinley will always remain an uninhabitable geographical space that can never be permanently "civilized," although Cook realizes that the rest of the Alaskan landscape will probably eventually be fully explored and thus potentially "civilized" by permanent settlements, becoming closed as a frontier wilderness. McKinley, however, allows "manly" Anglo-Saxon men the opportunity to return again and again to the rigors of its vertical topography in order to supposedly reinvigorate the sublimity of Anglo-Saxon masculinity, in turn ensuring the permanent health of the nation itself. 


\section{NOTES}

1. While there is no definitive truth regarding Cook's "success," it is generally accepted that Cook fabricated his account. See, for instance, Unsworth 221-28.

2. Throughout this essay, I use the term "wilderness" in the historical context of Cook's narrative.

3. On the call to annex Canada, see also Wrobel 21-22. For the reactions to the annexation movement in British Columbia, see Neunherz 118-33.

4. In response to the popular notion that Americans in the late nineteenth century uniformly believed that the purchase of Alaka was a mistake, Welch writes, "It is possibly congenial to our current self-esteem to believe that only in our generation have Americans appreciated the value of American ownership of Alaska. Such a view, if gratifying, is incorrect. Contemporary public opinion-as reflected in the newspapers of the day — was far from universally opposed to our purchase of Alaska" (103).

5. In chapter 2 of Nature's State, Kollin examines how in order to "solve" the problem of geographical contiguity, U.S. writers from the early twentieth century effectively annex Canada in their writings by aesthetically blurring the geographical distinction between Canada and the United States, particularly in writings about the Yukon. Their aesthetic concerns reflected a wider discourse in the United States and Canada about the eventual, possible institutional annexation of Canada by the United States.

6. On Muir and Young's role in configuring Alaska as the last frontier, see Kollin 28-39. See also Nash, Wilderness and the American Mind 279-86 on Muir's importance in transforming the image of Alaska from a barren wasteland to a landscape of aesthetic value as pristine wilderness. Nash also briefly points to the significance of Alaska as the last frontier.

7. On the power of naming, see also the introduction to Miller (1-8).

8. The sportsmen's goals were temporarily met with the creation of Mount McKinley National Park in 1917, which was conceived as a sportsmen's paradise. For a history of the park's origins, eventual reality, and failure as a workable idea, see Catton, chapters 4 and 5 (87-130).

9. This idea is an underlying theme of Richard Slotkin's trilogy Regeneration through Violence, The Fatal Enviromment, and Gunfighter Nation.

10. On Indian stereotypes, see Berkhofer 25-31.

11. Slotkin writes, "As the 'man who knows Indians,' the frontier hero stands between the opposed worlds of savagery and civilization, acting sometimes as mediator or interpreter between races and cultures" (Gunfighter 16).

12. See in particular Hoganson.

13. Again, see Slotkin's trilogy.

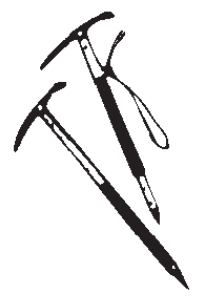




\section{WORKS CITED}

Abramson, Howard S. Hero in Disgrace: The Life of Arctic Explorer Frederick A. Cook. New York: Paragon House, 1991.

Bederman, Gail. Manliness and Civilization: A Cultural History of Gender and Race in the United States, 1880-1917. Chicago: University of Chicago Press, 1995.

Berkhofer, Robert F. The White Man's Indian: Images of the American Indian from Columbus to the Present. 1978. New York: Vintage Books, 1979.

Catton, Theodore. Inhabited Wilderness: Indians, Eskimos, and National Parks in Alaska. Albuquerque: University of New Mexico Press, 1997.

Cook, Frederick A. To the Top of the Continent: Discovery, Exploration, and Adventure in Sub-arctic Alaska. The First Ascent of Mt. McKinley, 1903-1906. 1908. Hurleyville, N.Y.: Frederick A. Cook Society, 1996.

Cronon, William. "Introduction: In Search of Nature." Uncommon Ground: Toward Reinventing Nature. Ed. William Cronon. New York: Norton, 1995. 23-56.

_. "The Trouble with Wilderness; or, Getting Back to the Wrong Nature." Uncommon Ground: Toward Reinventing Nature. Ed. William Cronon. New York: Norton, 1995. 69-90.

Deane, Seamus. Introduction. Nationalism, Colonialism, and Literature. Minneapolis: University of Minnesota Press, 1990. 3-19.

Ellis, Reuben. Vertical Margins: Mountaineering and the Landscapes of Neoimperialism. Madison: University of Wisconsin Press, 2001.

Hoganson, Kristen L. Fighting for American Manhood: How Gender Politics Provoked the Spanish-American and Philippine-American Wars. New Haven, Conn.: Yale University Press, 1998.

Kimmel, Michael. Manhood in America: A Cultural History. New York: Free Press, 1996.

Kollin, Susan. Nature's State: Imagining Alaska as the Last Frontier. Chapel Hill: University of North Carolina Press, 2001.

Lape, Noreen Groover. West of the Border: The Multicultural Literature of the Western American Frontiers. Athens: Ohio University Press, 2000.

Mazel, David. American Literary Environmentalism. Athens: University of Georgia Press, 2000.

Miller, J. Hillis. Topographies. Stanford, Calif.: Stanford University Press, 1995. Nash, Roderick. Introduction. The Call of the Wild (1900-1916). Ed. Roderick Nash. New York: George Braziller, 1970. 1-15.

- Wilderness and the American Mind. 3rd ed. New Haven, Conn.: Yale University Press, 1982.

Neunherz, Richard E. "'Hemmed In': Reactions in British Columbia to the Purchase of America." An Alaskan Anthology: Interpreting the Past. Ed. Stephen W. Haycox and Mary Childers Mangusso. Seattle: University of Washington Press, 1996. 118-33. 
Slotkin, Richard. The Fatal Environment: The Myth of the Frontier in the Age of Industrialization, 1800-1890. New York: Atheneum, 1985.

- Gunfighter Nation: The Myth of the Frontier in Twentieth-Century America. New York: Harper Perennial, 1993.

- Regeneration through Violence: The Mythology of the American Frontier, 1600-1860. Middletown, Conn.: Wesleyan University Press, 1973.

Unsworth, Walt. Hold the Heights: The Foundations of Mountaineering. Seattle, Wash.: Mountaineers, 1994.

Welch, Richard E., Jr. "American Public Opinion and the Purchase of Russian America." An Alaska Anthology: Interpreting the Past. Ed. Stephen W. Haycox and Mary Childers Mangusso. Seattle: University of Washington Press, 1996. 102-17.

Wrobel, David M. The End of American Exceptionalism: Frontier Anxiety from the Old West to the New Deal. Lawrence: University Press of Kansas, 1993.
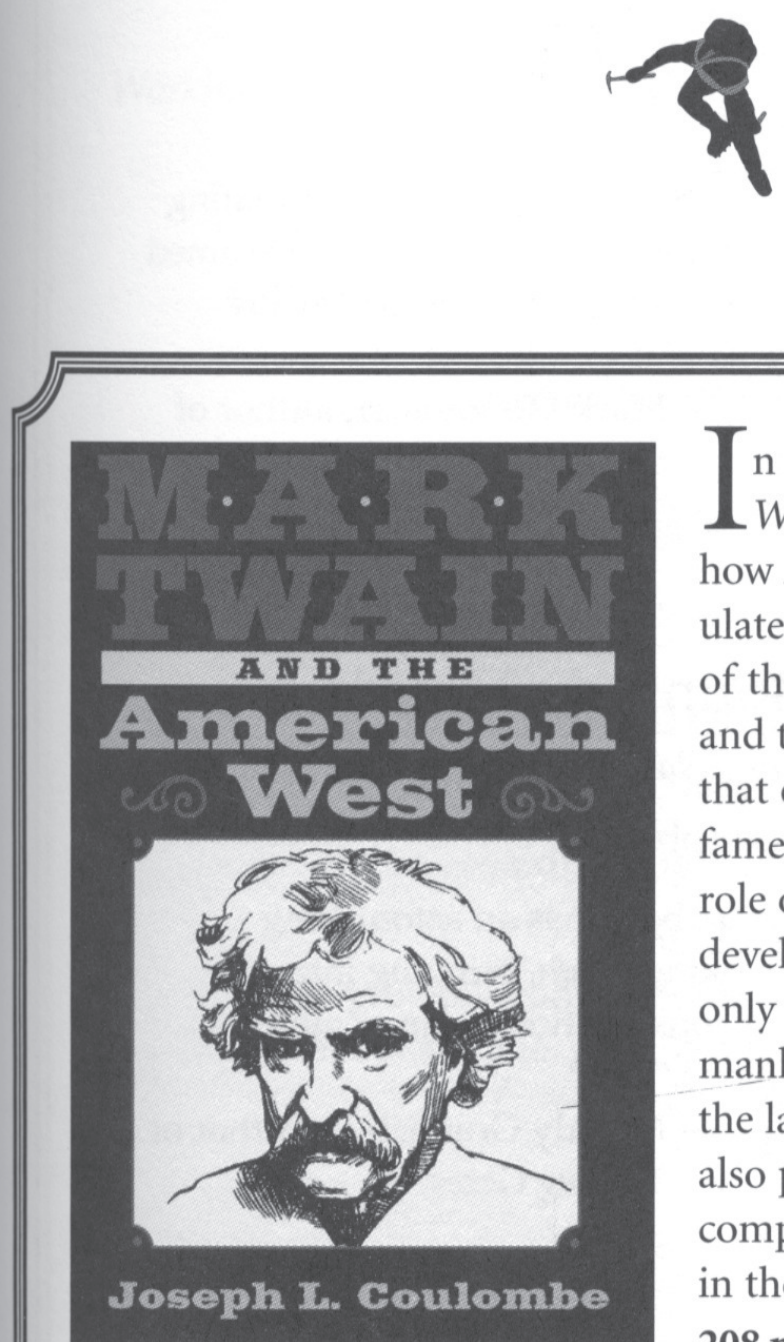

I $n$ Mark Twain and the American West, Joseph Coulombe explores how Mark Twain deliberately manipulated contemporary conceptions of the American West to create and then modify a public image that eventually won worldwide fame. He establishes the central role of the western region in the development of a persona that not only helped redefine American manhood and literary celebrity in the late nineteenth century, but also produced some of the most complex and challenging writings in the American canon.

208 pages, $\$ 29.95$

UNIVERSITY OF MISSOURI PRESS $1-800-828-1894$ www.system.missouri.edu/upress 